\title{
The Role of Androgens in Normal and Malignant Breast Tissue
}

\author{
Katharina Tiefenbacher Günter Daxenbichler \\ Department of Gynecology and Obstetrics, Medical University of Innsbruck, Austria
}

\section{Key Words}

Androgens - Paracrine mechanisms - Breast .

Breast cancer

\section{Summary}

Androgens, like estrogens, can be synthesized in the breast. As both active androgens and their corresponding receptors are present in breast tissue, we conclude that they play a role in breast physiology. This is supported by the fact that insufficient androgen production or sensitivity results in the development of gynecomastia. Complete androgen insensitivity due to receptor defects leads to normal female breast development in these $X Y$ women. While breast development is completely inhibited by male testosterone levels, partial but not total degradation of a developed breast by androgen treatment appears to be possible. Breast cancer in early stages seems to fulfill the prerequisites of androgen responsiveness. Androgen treatment of advanced breast cancer has shown similar effectiveness as anti-estrogen or estrogen-ablative therapy, but also considerable side effects. It has been speculated that the use of selective androgen modulators (SARMs), either alone or preferably in addition to anti-estrogens or aromatase inhibitors, may be a promising alternative to current therapy modalities in hormone-dependent breast cancer. In addition, future studies on the use of SARMs in prophylactic settings seem to be justified.

\author{
Schlüsselwörter \\ Androgene - Parakrine Mechanismen - Brust . \\ Brustkrebs
}

\section{Zusammenfassung}

Androgene, wie auch Östrogene, können in der Brust synthetisiert werden. Da sowohl aktive Androgene als auch der korrespondierende Rezeptor im Brustgewebe vorhanden sind, kann angenommen werden, dass sie auch eine physiologische Rolle spielen. Es gibt mehrere Hinweise dafür: Insuffiziente Androgenproduktion oder -sensitivität resultiert häufig in einer Gynäkomastie. Komplette Androgeninsensitivität aufgrund eines Androgenrezeptordefekts führt zu normaler Brustentwicklung bei den betroffenen XY-Frauen. Während die Brustentwicklung durch männliche Testosteronspiegel vollständig verhindert werden kann, zeigt sich unter Androgenbehandlung nur ein partieller Rückgang der bereits entwickelten Brust. Brustkrebs im Frühstadium scheint alle Voraussetzungen für eine Androgensensitivität zu haben. Die Androgenbehandlung des fortgeschrittenen Mammakarzinoms war in etwa gleich effektiv wie alle anderen additiven oder ablativen Hormontherapien, aber die Nebenwirkungen waren größer. Es wird vermutet, dass die Verwendung von selektiven Androgen-RezeptorModulatoren (SARMs), allein oder in Kombination mit Antiöstrogenen oder Aromatasehemmern, eine Erfolg versprechende Alternative zu derzeitigen Therapiemodalitäten beim hormonsensitiven Mammakarzinom wäre. Auch Studien zur Verwendung von SARMs in der Prophylaxe des Brustkrebses scheinen gerechtfertigt.

\section{KARGER}

Fax +497614520714

Information@Karger.de

www.karger.com (c) 2008 S. Karger GmbH, Freiburg

Accessible online at:

www.karger.com/brc
Prof. Dr. med. Günter Daxenbichler

Universitätsklinik für Gynäkologie und Geburtshilfe

Medizinische Universität Innsbruck

Anichstraße 35, 6020 Innsbruck, Austria

Tel. +43 512 504-23113, Fax -23112

guenter.daxenbichler@i-med.ac.at 


\section{General Considerations}

The aim of this review is to highlight the role of androgens in the female mammary gland, both in normal and cancerous tissue.

Androgens are C19-steroid hormones that are produced in the ovaries, adrenal glands and peripheral tissues. The term 'androgen' is in fact only valid for testosterone ( $\mathrm{T}$ ) and dihydrotestosterone (DHT). T can also be converted to estradiol and is thus a precursor for both the 'pure' androgen DHT and the 'pure' estrogen estradiol. Dehydroepiandrosterone (DHEA), DHEA sulfate (DHEA-S) and androstendione (Adione) are not able to bind to and activate the androgen receptor (AR), and they serve as precursors for androgen as well as estrogen synthesis. Therefore, these substances are considered prohormones.

Only a small amount of T (1-3\%) circulates free and unbound in the blood. Most of it is bound either to albumin (25-35\%) or to sex hormone-binding globulin (SHBG) (65-75\%) [1] The uptake of SHBG-bound steroids into the cell has been found to be mediated by a receptor called megalin [2]. Expression of megalin mRNA has also been detected in mammary epithelial cells [3].

Most steroids circulate as precursors such as DHEA, DHEA$\mathrm{S}$ or A-dione through the body. Steroid-dependent tissues are able to synthesize active steroid hormones from these precursors. Labrie calls this phenomenon 'intracrinology' [4]. However, this would mean that one and the same cell produces the hormone and the corresponding receptor. Such a construction would imply independence of a cell from others, which would be difficult to incorporate within a comprehensive model of regulation of mammary gland formation and function. The term 'paracrinology' would thus appear more appropriate as different cells communicate with each other.

\section{Androgen-Converting Enzymes in the Breast}

To form DHT from DHEA-S, steroid sulfatase (STS), 33-hy-

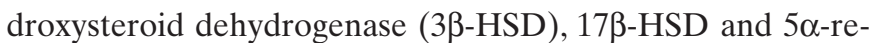
ductase are required. The synthesis of androgens as well as estrogens is possible from DHEA-S and DHEA; this occurs through the combination of aromatase and the enzymes named above.

STS hydrolyzes steroid sulfates to their more active, unconjugated forms. It is responsible for the conversion of DHEA-S to DHEA and estrone (E1)-S to E1. The sulfated inactive precursors possess a much longer half-life in the blood than DHEA or E1, and are therefore the ideal transportation form for steroid hormones.

As to the localization of STS in the normal human mammary gland, Tobacman et al. [5] have detected STS mRNA expression and enzymatic activity in myoepithelial cells. They therefore conclude that myoepithelial cells may play an important role in providing unsulfated steroid hormones to the mammary secretory epithelium. In contrast to these findings, Suzuki et al. [6] and Miki et al. [7] report only very low levels of STS mRNA expression and no STS immunoreactivity in normal breast tissue.

Several groups report elevated STS expression and activity in cancerous breast tissue in comparison to non-malignant breast tissue [6, 8]. Additionally, Zaichuk et al. [9] demonstrate that STS expression is elevated only in estrogen receptor $(\mathrm{ER}) \alpha-$ positive breast cancer while it is even lowered in ER $\alpha$-negative cancer tissues.

Comparisons of STS versus aromatase activities have attached great importance to the sulfatase pathway [10]. Both in normal and in cancerous mammary gland tissue, the measured activity of STS has been shown to be significantly higher than the activity of aromatase [11].

$3 \beta$-HSD is necessary for the conversion of DHEA to A-dione. Two isoforms of $3 \beta$-HSD exist. While type 2 has been found only in the adrenals, testis and ovaries, type 1 was isolated from the placenta and several peripheral tissues including normal and cancerous breast tissue $[12,13]$. 3 $\beta$-HSD was present in normal mammary gland in fibroblasts and epithelial cells, but not in myoepithelial cells [14].

Currently, 15 isoforms of $17 \beta$-HSD are known [15]. Types 2, 4, $6,8,9,10,11$ and 14 catalyze the oxidation of androgens and estrogens, while types $1,3,5,7$ and 12 catalyze the reduction of these steroid hormones. The oxidative enzymes use NAD $(\mathrm{P})^{+}$ as a cofactor and cause inactivation of their substrates, whereas the reductive isoforms lead to activation by means of $\mathrm{NAD}(\mathrm{P}) \mathrm{H}[16]$.

In normal breast tissue, oxidation of estrogens predominates, while the reductive pathway is strongly favored in hormonedependent breast tumors $[17,18]$. The conversion of $17 \beta$-estradiol (E2) to E1 is dominant in hormone-independent breast cancer [19].

$17 \beta$-HSD type 1 mainly converts E1 to E2, and was found to be expressed in both normal and cancerous mammary epithelial cells [18]. Day et al. [20] recently demonstrated that $17 \beta$ HSD type 1 is the main $17 \beta$-HSD isoform in converting E1 to E2 in breast cancer tissue. In contrast, Song et al. [21] postulate that $17 \beta$-HSD type 7 and most notably type 12 are the most widely expressed reductive isoenzymes in breast carcinoma cells and are therefore of greater interest.

Furthermore, Gangloff et al. [22] describe the inactivation of DHT by $17 \beta$-HSD type 1 to either $3 \beta$-androstanediol or androstandion. If this enzyme is not only capable of providing the most potent estrogen E2 but also of inactivating the most potent opponent of E2, this would imply a further support of estrogenic action.

17 $\beta$-HSD types 3 and 5 synthesize T from A-dione. Type 3 is mainly located in the testes, while type 5 is expressed in peripheral tissues such as the prostate and the breast. 17 $\beta$-HSD type 5 is the only member of the $17 \beta$-HSDs that belongs to the aldo-keto reductase family and not to the short-chain alcohol 
dehydrogenase superfamily. It has been localized immunocytochemically in the epithelium of acini and ducts of the mammary gland [14], and has also been detected in breast cancer tissue [23].

17ß-HSD type 2 converts T to A-dione and E2 to E1 [18]. It is expressed in normal mammary epithelial cells, and is believed to play a major role in inactivating E2 [18]. As to its appearance in cancerous breast cells, Suzuki et al. [24] report almost no immunoreactivity in 111 examined tissues, whereas Gunnarsson et al. [25] find $17 \beta$-HSD type 2 expression in $69 \%$ of 230 examined tissues.

$5 \alpha$-Reductase catalyzes the conversion of T to DHT. Of the two identified isoforms, type 1 is assumed to be of more importance in the mammary gland than type 2 [23]. Expression and activity of the two isoenzymes has been detected in both normal and cancerous breast tissue, but in significantly higher amounts in tumorous tissue $[23,26]$.

Aromatase expression and activity has been found in stromal cells in normal and cancerous breast tissue [27, 28]. It is still a matter of controversy whether it is also located in epithelial and carcinoma cells [29].

Aromatase converts A-dion to E1 and T to E2. But it has also been suggested that $\mathrm{T}$ may be the preferred substrate in breast cancer cells [30]. Suzuki et al. [23] propose the influence of aromatase on intratumoral DHT concentrations. Accordingly, by converting $\mathrm{T}$ to $\mathrm{E} 2$, the enzyme decreases $\mathrm{T}$ concentrations; the less $\mathrm{T}$ is available, the less DHT can be produced.

\section{The Androgen Receptor in the Breast}

Not only the uptake of androgens and/or their precursors and the conversion into biologically active forms, but also the presence of corresponding receptors is a prerequisite to enable androgen action in a tissue.

There have only been a small number of studies dealing with the localization of the AR in the normal human mammary gland. However, it has been possible to detect immunohistochemical staining of the AR in the nuclei of mammary gland tissue epithelial cells. Studies have found the AR in ductal and alveolar cells [31-35]. Additionally, Birrell et al. [35] report occasional cytoplasmatic staining. Kimura et al. [33] and Birrell et al. [35] detect at least some AR immunoreactivity in myoepithelial cells, unlike Janssen et al. [34] and Ruizefeld de Winter et al. [32]. The occurrence of the AR in the stroma is still uncertain. Kimura et al. [33] and Zhuang et al. [31] observe the presence of AR in stromal cells, whereas Birrell et al. [35] and Janssen et al. [34] find only sporadic occurrence in stromal cells.

In contrast to the limited number of studies on AR expression in normal breast tissues, there have been numerous publications about the localization of AR in breast tumors. Most of them report AR expression in about $70-90 \%$ of the examined cases [23, 36-40]. Some groups report associations between
AR status and tumor type, grade and stage [36, 37], while others do not [40]. Conflicting findings are also found with regard to correlations between AR status and prognosis in terms of disease-free survival.

\section{Androgen Concentrations in the Breast}

Measurements of androgens in the mammary gland have revealed the presence of T and DHT in both normal and tumorous tissues. Suzuki et al. [41] report mean DHT concentrations in non-tumorous samples of $97 \pm 9 \mathrm{pg} / \mathrm{g}$. Measured DHT concentrations in invasive ductal carcinoma and in ductal carcinoma in situ tissue were significantly higher [23, 41-45]. Moreover, decreases in intratumoral DHT levels have been associated with increases in malignity or dedifferentiation [42, 45]. As estradiol levels in breast cancer tissue have been found to be independent of serum levels due to local production [46, 47], the same has been assumed for DHT. Studies on tissue versus serum concentrations of DHT have supported this assumption $[43,44]$.

\section{Possible Functions of Androgens in the Breast}

As all the enzymes crucial for T and DHT production, measurable androgen concentrations and AR are present in the breast, one can conclude that androgens play a role in the regulation of the mammary gland, not only in cancer but also under normal conditions.

\section{Inhibition of Proliferation in the Normal Mammary Gland}

Recently published data provide evidence for the widespread theory of androgens opposing estrogens in the mammary gland. Studies on rhesus monkeys demonstrate the inhibiting influence of androgens on mammary epithelial proliferation by reducing E2-induced proliferation [48, 49]. The same results have been shown in rodent mammary gland [50].

Observations indicate similar effects of androgens in humans. The impact of $\mathrm{T}$ addition to combined estrogen and progesterone hormone replacement therapy on the postmenopausal breast has been studied by Hofling et al. [51]. While the estrogen and progesterone combination produced a considerable increase of breast cell proliferation, no significant changes were observed when $\mathrm{T}$ was added [51]. This is another indication of androgens blocking stimulatory influences in the mammary gland.

Observations regarding anabolic androgen steroids (AAS) provide further information. The use and abuse of AAS in females leads to elevated $\mathrm{T}$ levels within normal male ranges [52]. One of the side effects of AAS is the reduction of breast size. Both female-to-male transsexuals and athletes taking 
AAS have self-reported a reduction of breast size [53]. But not all of the participants of these studies noticed this effect. The atrophy of the mammary gland has been verified histologically by several groups [54-56]. In contrast, Burgess and Shousha [57] found no atrophic changes in breast tissues among female-to-male transsexuals 1 month after stopping AAS treatment. Moreover, it should be mentioned that mastectomy is an inherent part of gender reassignment for femaleto-male transsexuals. This indicates that, even with prolonged AAS treatment, it is not possible to completely reverse previous breast development.

\section{Inhibition of Breast Development}

Androgens are thought to inhibit mammary gland development. This is supported by the fact that males usually do not develop breasts. In patients with hypogonadism and androgen deficiency, however, e.g. in Klinefelter's syndrome or partial androgen insensitivity (PAIS), gynecomastia is often observed [58]. Genotypically male individuals suffering from complete androgen insensitivity (CAIS) develop morphologically normal female breasts during puberty [58].

Girls with congenital adrenal hyperplasia $(\mathrm{CAH})$ and androgen excess do not undergo pubertal thelarche [59]. Overall, this may be an indicator of the complete inhibition of pubertal breast development by androgens.

\section{Inhibition of Proliferation in Breast Cancer}

Numerous studies describe the effects of androgens on breast cancer cells as inhibiting proliferation [60]. In ZR-75-1, T47D, HCC 1500, CAMA-1 and MFM-223 cells, DHT inhibits proliferation [61, 62]. Conflicting results have been reported for MCF-7 cells. While some groups observe stimulation [62], others find inhibition of proliferation by DHT [61]. The effects of androgens on breast cancer cell lines seem to depend on the presence of the AR, the concentration and type of androgen used and the presence of co-regulatory proteins [60]. Furthermore, apoptotic effects of androgens on breast cancer cell lines have been shown [63]. Similar observations have been made for cancer cells of the prostate [64].

\section{Androgen Receptor Mutations and Breast Cancer}

The assumption that androgens protect the mammary gland from developing cancer is further supported by studies on AR polymorphisms. The AR gene contains a CAG and a GGN repeat length polymorphism. The CAG repeat length has been shown to be inversely associated with transcriptional activity of the AR gene. A long repeat length means less activity, while a shorter CAG repeat length results in higher transcriptional activity [65]. Some groups suggest that short CAG repeats possibly reduce and long repeats possibly enhance breast cancer risk in women [66]. Others report that longer CAG repeats are associated with higher breast cancer risk in women with first-degree family history of breast cancer [67]. And still others find no association between CAG repeat length and breast cancer risk [68]. Although higher breast cancer risk via less activity of the AR through longer CAG repeats would fit perfectly with the assumption mentioned above, these inconsistent results do not permit us to draw any final conclusions.

Another approach to the role of androgens in breast cancer is through research on AR gene mutations. Thus far, there have only been three reports of such alterations [69-71]. All described mutations are located in the region encoding the DNA binding domain (DBD), and are found in male PAIS patients with breast cancer. It has been speculated that the changes in the DBD of the AR may either lead to a decrease in activity or to the binding of the AR to estrogen-responsive elements. Poujol et al. [72] observe weaker binding of the mutant AR to androgen-responsive elements, but no binding to estrogen-responsive elements. However, analysis of male non-PAIS breast cancer tissues for AR mutations revealed no AR gene alterations [73]. Furthermore, there have been neither reports of elevated breast cancer risk nor case reports of breast cancer in CAIS patients. Thus, it can be concluded that AR mutations do not necessarily lead to breast cancer development. If androgens represented the sole element inhibiting breast cell proliferation, the complete loss of AR function in CAIS would cause uncontrolled proliferation. This would result either in macromastia or in elevated breast cancer risk. As there have been no reports of breast cancer in CAIS patients, one could conclude that there is an alternative pathway that inhibits excessive breast cell proliferation.

No further AR gene mutations with impact on breast cancer development are known [74]. Currently, all identified AR mutations are provided on www.mcgill.ca/androgendb.

All attempts to detect AR gene mutations in breast cancer cells have been unsuccessful [75, 76]. However, Shan et al. [76] postulate that the loss of AR expression in AR-negative female breast cancer may be caused by inactivation of the active X-chromosome. Zhu et al. [75] discovered another irregularity regarding AR mRNA in breast cancer. An exon 3 deletion splice variant was detected in part of the cancer tissues, but not in normal breast tissue.

\section{Androgen Serum Levels and Breast Cancer}

Evaluating associations between serum steroid levels and breast cancer risk, most studies report increased risk of breast cancer in postmenopausal women with elevated serum levels $[77,78]$. As the mammary gland is capable of converting adrenal precursors into estradiol and DHT via several intermediates, these results do not necessarily indicate higher pro- 
liferation stimulation as a consequence of elevated serum hormone levels. It seems more probable that the breast acts as an endocrine gland that contributes significantly to postmenopausal blood levels of steroidal sex hormones. Elevated levels might then reflect higher breast turnover, including higher proliferation, and thus a higher risk of developing cancer. It has not been proved that physiological blood levels of sex steroids have a direct influence on breast homeostasis. Male T levels and pregnancy estradiol and progesterone are at least one order of magnitude higher than physiologically active concentrations, which may allow them to interfere directly with intramammarian proliferation and differentiation mechanisms. Inadequately low T levels in men seem to be associated with increased risk of male breast cancer [79].

\section{Androgen Therapy in Breast Cancer}

Assuming that androgens are able to inhibit proliferation of both normal and cancerous breast tissue, androgen therapy would be a logical conclusion. Since the 1930s there have been attempts to treat breast cancer with androgens, in particular advanced breast cancer. The reported efficacy of around $20-30 \%$ is similar to that of other hormonal or anti-hormonal approaches [80]. Karydas et al. [81] analyzed relapse-free and overall survival in patients receiving adjuvant androgen treatment (T propionate $200 \mathrm{mg}$ s.c.). No survival advantage for the treated group was observed. However, no information on serum levels is provided, which could allow us to assess whether the applied doses were appropriate. Due to side effects and the advent of anti-estrogens and estrogen depletion strategies, androgen therapy in breast cancer was abandoned. Garreau et al. [82] recently demonstrated the efficacy of combined treatment with DHEA and an aromatase inhibitor in AR-transfected HC 1806 breast cancer cells. The cell death rate was notably enhanced by this treatment. The authors conclude that androgen therapy in AR-positive and ER/ progesterone receptor (PR)-negative breast cancer could increase survival rates in combination with chemotherapy.

The clinical use of androgens in breast cancer treatment has been limited due to adverse effects. To eliminate side effects such as virilization, the development of selective androgen receptor modulators (SARMs) could be a promising approach. It needs to ensure, however, that either the androgen used is non-aromatizable or that aromatase activity is blocked to prevent adverse effects on breast cancer cell proliferation. SARMs and anti-estrogenic treatment should theoretically act synergistically in inhibiting breast cancer growth.

\section{References}

1 Dunn JF, Nisula BC, Rodbard D: Transport of steroid hormones: binding of 21 endogenous steroids to both testosterone-binding globulin and corticosteroid-binding globulin in human plasma. $\mathrm{J}$ Clin Endocrinol Metab 1981;53:58-68.

$\checkmark 2$ Hammes A, Andreassen TK, Spoelgen R, Raila J, Hubner N, Schulz H, Metzger J, Schweigert FJ, Luppa PB, Nykjaer A, Willnow TE: Role of endocytosis in cellular uptake of sex steroids. Cell 2005; 122:751-762.

3 Rowling MJ, Kemmis CM, Taffany DA, Welsh J: Megalin-mediated endocytosis of vitamin D binding protein correlates with 25-hydroxycholecalciferol actions in human mammary cells. J Nutr 2006; 136:2754-2759.

4 Labrie F: Intracrinology. Mol Cell Endocrinol 1991; 78:C113-C118.

${ }_{5}$ Tobacman JK, Hinkhouse M, Khalkhali-Ellis Z: Steroid sulfatase activity and expression in mammary myoepithelial cells. J Steroid Biochem Mol Biol 2002;81:65-68.

6 Suzuki T, Miki Y, Nakata T, Shiotsu Y, Akinaga S, Inoue K, Ishida T, Kimura M, Moriya T, Sasano H: Steroid sulfatase and estrogen sulfotransferase in normal human tissue and breast carcinoma. J Steroid Biochem Mol Biol 2003;86:449-454.

7 Miki Y, Nakata T, Suzuki T, Darnel AD, Moriya T, Kaneko C, Hidaka K, Shiotsu Y, Kusaka H, Sasano $\mathrm{H}$ : Systemic distribution of steroid sulfatase and estrogen sulfotransferase in human adult and fetal tissues. J Clin Endocrinol Metab 2002;87:5760-5768.

$\checkmark$ Evans TR, Rowlands MG, Law M, Coombes RC: Intratumoral oestrone sulphatase activity as a prognostic marker in human breast carcinoma. $\mathrm{Br} \mathrm{J}$ Cancer 1994;69:555-561.
9 Zaichuk T, Ivancic D, Scholtens D, Schiller C, Khan SA: Tissue-specific transcripts of human steroid sulfatase are under control of estrogen signaling pathways in breast carcinoma. J Steroid Biochem Mol Biol 2007;105:76-84.

10 Reed MJ, Purohit A, Woo LWL, Newman SP, Potter BVL: Steroid sulfatase: molecular biology, regulation, and inhibition. Endocr Rev 2005;26:171-202.

11 Chetrite GS, Cortes-Prieto J, Philippe JC, Wright F, Pasqualini JR: Comparison of estrogen concentrations, estrone sulfatase and aromatase activities in normal, and in cancerous, human breast tissues. $\mathrm{J}$ Steroid Biochem Mol Biol 2000;72:23-27.

12 Luu The V, Lachance Y, Labrie C, Leblanc G, Thomas JL, Strickler RC, Labrie F: Full length cDNA structure and deduced amino acid sequence of human 3 beta-hydroxy-5-ene steroid dehydrogenase. Mol Endocrinol 1989;3:1310-1312.

13 Gingras S, Moriggl R, Groner B, Simard J: Induction of 3beta-hydroxysteroid dehydrogenase/delta 5-delta4 isomerase type 1 gene transcription in human breast cancer cell lines and in normal mammary epithelial cells by interleukin-4 and interleukin-13. Mol Endocrinol 1999;13:66-81.

14 Pelletier G, Luu-The V, El-Alfy M, Li S, Labrie F: Immunoelectron microscopic localization of 3betahydroxysteroid dehydrogenase and type 5 17betahydroxysteroid dehydrogenase in the human prostate and mammary gland. J Mol Endocrinol 2001; 26:11-19.

15 Day JM, Tutill HJ, Purohit A, Reed MJ: Design and validation of specific inhibitors of 17 \{beta\}-hydroxysteroid dehydrogenases for therapeutic application in breast and prostate cancer, and in endometriosis. Endocr Relat Cancer 2008;15:665-692.
6 Labrie F, Luu-The V, Labrie C, Bélanger A, Simard $\mathrm{J}$, Lin S, Pelletier G: Endocrine and intracrine sources of androgens in women: inhibition of breast cancer and other roles of androgens and their precursor dehydroepiandrosterone. Endocr Rev 2003; 24:152-182.

17 Purohit A, Tutill HJ, Day JM, Chander SK, Lawrence HR, Allan GM, Fischer DS, Vicker N, Newman SP, Potter BVL, Reed MJ: The regulation and inhibition of 17beta-hydroxysteroid dehydrogenase in breast cancer. Mol Cell Endocrinol 2006; 248:199-203.

18 Miettinen M, Mustonen M, Poutanen M, Isomaa V, Wickman M, Söderqvist G, Vihko R, Vihko P: 17Beta-hydroxysteroid dehydrogenases in normal human mammary epithelial cells and breast tissue. Breast Cancer Res Treat 1999;57:175-182.

19 Nguyen BL, Chetrite G, Pasqualini JR: Transformation of estrone and estradiol in hormone-dependent and hormone-independent human breast cancer cells. Effects of the antiestrogen ICI 164,384, danazol, and promegestone (R-5020). Breast Cancer Res Treat 1995;34:139-146.

20 Day JM, Foster PA, Tutill HJ, Parsons MFC, Newman SP, Chander SK, Allan GM, Lawrence HR, Vicker N, Potter BVL, Reed MJ, Purohit A: 17Betahydroxysteroid dehydrogenase type 1 , and not type 12 , is a target for endocrine therapy of hormonedependent breast cancer. Int J Cancer 2008;122: 1931-1940.

21 Song D, Liu G, Luu-The V, Zhao D, Wang L, Zhang H, Xueling G, Li S, Désy L, Labrie F, Pelletier G: Expression of aromatase and 17beta-hydroxysteroid dehydrogenase types 1,7 and 12 in breast cancer. An immunocytochemical study. J Steroid Biochem Mol Biol 2006;101:136-144. 
22 Gangloff A, Shi R, Nahoum V, Lin S: Pseudo-symmetry of C19 steroids, alternative binding orientations, and multispecificity in human estrogenic 17beta-hydroxysteroid dehydrogenase. FASEB J 2003;17:274-276.

-23 Suzuki T, Miki Y, Moriya T, Akahira J, Ishida T, Hirakawa $\mathrm{H}$, Yamaguchi $\mathrm{Y}$, Hayashi S, Sasano H: 5Alpha-reductase type 1 and aromatase in breast carcinoma as regulators of in situ androgen production. Int J Cancer 2007;120:285-291.

24 Suzuki T, Moriya T, Ariga N, Kaneko C, Kanazawa M, Sasano H: 17Beta-hydroxysteroid dehydrogenase type 1 and type 2 in human breast carcinoma: a correlation to clinicopathological parameters. $\mathrm{Br}$ J Cancer 2000;82:518-523.

-25 Gunnarsson C, Hellqvist E, Stål O: 17Beta-hydroxysteroid dehydrogenases involved in local oestrogen synthesis have prognostic significance in breast cancer. Br J Cancer 2005;92:547-552.

26 Wiebe JP, Muzia D, Hu J, Szwajcer D, Hill SA, Seachrist JL: The 4-pregnene and 5alpha-pregnane progesterone metabolites formed in nontumorous and tumorous breast tissue have opposite effects on breast cell proliferation and adhesion. Cancer Res 2000;60:936-943.

27 Brodie A, Lu Q, Nakamura J: Aromatase in the normal breast and breast cancer. J Steroid Biochem Mol Biol 1997;61:281-286.

28 Santen RJ, Martel J, Hoagland M, Naftolin F, Roa L, Harada N, Hafer L, Zaino R, Santner SJ: Stroma spindle cells contain aromatase in human breast tumors. J Clin Endocrinol Metab 1994;79:627-632.

29 Miki Y, Suzuki T, Sasano H: Controversies of aromatase localization in human breast cancer - stromal versus parenchymal cells. J Steroid Biochem Mol Biol 2007;106:97-101.

-30 Sonne-Hansen K, Lykkesfeldt AE: Endogenous aromatization of testosterone results in growth stimulation of the human MCF-7 breast cancer cell line. J Steroid Biochem Mol Biol 2005;93:25-34.

-31 Zhuang Y, Saaristo R, Ylikomi T: An in vitro longterm culture model for normal human mammary gland: expression and regulation of steroid receptors. Cell Tissue Res 2003;311:217-226.

\32 Ruizeveld de Winter JA, Trapman J, Vermey M, Mulder E, Zegers ND, van der Kwast TH: Androgen receptor expression in human tissues: an immunohistochemical study. J Histochem Cytochem 1991;39:927-936.

33 Kimura N, Mizokami A, Oonuma T, Sasano H, Nagura H: Immunocytochemical localization of androgen receptor with polyclonal antibody in paraffin-embedded human tissues. J Histochem Cytochem 1993;41:671-678.

-34 Janssen PJ, Brinkmann AO, Boersma WJ, Van der Kwast TH: Immunohistochemical detection of the androgen receptor with monoclonal antibody F39.4 in routinely processed, paraffin-embedded human tissues after microwave pre-treatment. J Histochem Cytochem 1994;42:1169-1175.

-35 Birrell SN, Butler LM, Harris JM, Buchanan G, Tilley WD: Disruption of androgen receptor signaling by synthetic progestins may increase risk of developing breast cancer. FASEB J 2007;21: 2285-2293.

36 Riva C, Dainese E, Caprara G, Rocca PC, Massarelli G, Tot T, Capella C, Eusebi V: Immunohistochemical study of androgen receptors in breast carcinoma. Evidence of their frequent expression in lobular carcinoma. Virchows Arch 2005;447:695-700.

37 Narita D, Raica M, Suciu C, Cîmpean A, Anghel A: Immunohistochemical expression of androgen receptor and prostate-specific antigen in breast cancer. Folia Histochem Cytobiol 2006;44:165-172.
38 Kuenen-Boumeester V, Van der Kwast TH, van Putten WL, Claassen C, van Ooijen B, HenzenLogmans SC: Immunohistochemical determination of androgen receptors in relation to oestrogen and progesterone receptors in female breast cancer. Int J Cancer 1992;52:581-584.

39 Isola JJ: Immunohistochemical demonstration of androgen receptor in breast cancer and its relationship to other prognostic factors. J Pathol 1993;170: 31-35.

40 Gonzalez LO, Corte MD, Vazquez J, Junquera S, Sanchez R, Alvarez AC, Rodriguez JC, Lamelas ML, Vizoso FJ: Androgen receptor expression in breast cancer: relationship with clinicopathological characteristics of the tumors, prognosis, and expression of metalloproteases and their inhibitors. BMC Cancer 2008;8:149.

41 Suzuki T, Miki Y, Moriya T, Akahira J, Hirakawa $\mathrm{H}$, Ohuchi N, Sasano H: In situ production of sex steroids in human breast carcinoma. Med Mol Morphol 2007;40:121-127.

42 Shibuya R, Suzuki T, Miki Y, Yoshida K, Moriya T, Ono K, Akahira J, Ishida T, Hirakawa H, Evans DB, Sasano H: Intratumoral concentration of sex steroids and expression of sex steroid-producing enzymes in ductal carcinoma in situ of human breast. Endocr Relat Cancer 2008;15:113-124.

43 Secreto G, Venturelli E, Bucci A, Piromalli D, Fariselli G, Galante E: Intratumour amount of sex steroids in elderly breast cancer patients. An approach to the biological characterization of mammary tumours in the elderly. J Steroid Biochem Mol Biol 1996;58:557-561.

44 Recchione C, Venturelli E, Manzari A, Cavalleri A, Martinetti A, Secreto G: Testosterone, dihydrotestosterone and oestradiol levels in postmenopausal breast cancer tissues. J Steroid Biochem Mol Biol 1995;52:541-546.

45 Mistry P, Griffiths K, Maynard PV: Endogenous C19-steroids and oestradiol levels in human primary breast tumour tissues and their correlation with androgen and oestrogen receptors. J Steroid Biochem 1986;24:1117-1125.

46 van Landeghem AA, Poortman J, Nabuurs M, Thijssen JH: Endogenous concentration and subcellular distribution of estrogens in normal and malignant human breast tissue. Cancer Res 1985; 45:2900-2906.

47 Blankenstein MA, van de Ven J, Maitimu-Smeele I, Donker GH, de Jong PC, Daroszewski J, Szymczak J, Milewicz A, Thijssen JH: Intratumoral levels of estrogens in breast cancer. J Steroid Biochem Mol Biol 1999;69:293-297.

48 Zhou J, Ng S, Adesanya-Famuiya O, Anderson K, Bondy CA: Testosterone inhibits estrogen-induced mammary epithelial proliferation and suppresses estrogen receptor expression. FASEB J 2000;14: 1725-1730.

49 Dimitrakakis C, Zhou J, Wang J, Belanger A, LaBrie F, Cheng C, Powell D, Bondy C: A physiologic role for testosterone in limiting estrogenic stimulation of the breast. Menopause 2003;10: 292-298.

50 Jayo MJ, Register TC, Hughes CL, Blas-Machado U, Sulistiawati E, Borgerink H, Johnson CS: Effects of an oral contraceptive combination with or without androgen on mammary tissues: a study in rats. J Soc Gynecol Investig 2000;7:257-265.

51 Hofling M, Hirschberg AL, Skoog L, Tani E, Hägerström T, von Schoultz B: Testosterone inhibits estrogen/progestogen-induced breast cell proliferation in postmenopausal women. Menopause 2007;14:183-190.
52 Moore E, Wisniewski A, Dobs A: Endocrine treatment of transsexual people: a review of treatment regimens, outcomes, and adverse effects. J Clin Endocrinol Metab 2003;88:3467-3473.

53 Mueller A, Kiesewetter F, Binder H, Beckmann MW, Dittrich R: Long-term administration of testosterone undecanoate every 3 months for testosterone supplementation in female-to-male transsexuals. J Clin Endocrinol Metab 2007;92: 3470-3475.

54 Sapino A, Pietribiasi F, Godano A, Bussolati G: Effect of long-term administration of androgens on breast tissues of female-to-male transsexuals. Ann N Y Acad Sci 1990;586:143-145.

55 Futterweit W, Schwartz IS: Histopathology of the breasts of 12 women receiving long-term exogenous androgen therapy. Mt Sinai J Med 1988;55: 309-312.

56 Slagter MH, Gooren LJG, Scorilas A, Petraki CD Diamandis EP: Effects of long-term androgen administration on breast tissue of female-to-male transsexuals. J Histochem Cytochem 2006;54:905-910.

57 Burgess HE, Shousha S: An immunohistochemical study of the long-term effects of androgen administration on female-to-male transsexual breast: a comparison with normal female breast and male breast showing gynaecomastia. J Pathol 1993;170: 37-43.

58 Quigley CA, De Bellis A, Marschke KB, el-Awady MK, Wilson EM, French FS: Androgen receptor defects: historical, clinical, and molecular perspectives. Endocr Rev 1995;16:271-321.

59 New MI: An update of congenital adrenal hyperplasia. Ann N Y Acad Sci 2004;1038:14-43.

60 Somboonporn W, Davis SR: Testosterone effects on the breast: implications for testosterone therapy for women. Endocr Rev 2004;25:374-388.

61 Ortmann J, Prifti S, Bohlmann MK, RehbergerSchneider S, Strowitzki T, Rabe T: Testosterone and 5 alpha-dihydrotestosterone inhibit in vitro growth of human breast cancer cell lines. Gynecol Endocrinol 2002;16:113-120.

62 Birrell SN, Bentel JM, Hickey TE, Ricciardelli C, Weger MA, Horsfall DJ, Tilley WD: Androgens induce divergent proliferative responses in human breast cancer cell lines. J Steroid Biochem Mol Biol 1995;52:459-467.

63 Lapointe J, Fournier A, Richard V, Labrie C: Androgens down-regulate bcl-2 protooncogene expression in ZR-75-1 human breast cancer cells. Endocrinology 1999;140:416-421.

64 Hatzoglou A, Kampa M, Kogia C, Charalampopoulos I, Theodoropoulos PA, Anezinis P, Dambaki C, Papakonstanti EA, Stathopoulos EN, Stournaras C, Gravanis A, Castanas E: Membrane androgen receptor activation induces apoptotic regression of human prostate cancer cells in vitro and in vivo. $\mathrm{J}$ Clin Endocrinol Metab 2005;90:893-903.

65 Chamberlain NL, Driver ED, Miesfeld RL: The length and location of CAG trinucleotide repeats in the androgen receptor N-terminal domain affect transactivation function. Nucleic Acids Res 1994; 22:3181-3186.

66 González A, Javier Dorta F, Rodriguez G, Brito B Rodríguez MADC, Cabrera A, Díaz-Chico JC, Reyes R, Aguirre-Jaime A, Nicolás Díaz-Chico B Increased risk of breast cancer in women bearing a combination of large CAG and GGN repeats in the exon 1 of the androgen receptor gene. Eur J Cancer 2007;43:2373-2380.

67 Wang W, John EM, Ingles SA: Androgen receptor and prostate-specific antigen gene polymorphisms and breast cancer in African-American women. Cancer Epidemiol Biomarkers Prev 2005;14: 2990-2994. 
-68 Cox DG, Blanché H, Pearce CL, Calle EE, Colditz GA, Pike MC, Albanes D, Allen NE, Amiano P, Berglund G, Boeing H, Buring J, Burtt N, Canzian F, Chanock S, Clavel-Chapelon F, Feigelson HS, Freedman M, Haiman CA, Hankinson SE, Henderson BE, Hoover R, Hunter DJ, Kaaks R, Kolonel L, Kraft P, LeMarchand L, Lund E, Palli D, Peeters PHM, Riboli E, Stram DO, Thun M, Tjonneland A, Trichopoulos D, Yeager M: A comprehensive analysis of the androgen receptor gene and risk of breast cancer: results from the National Cancer Institute Breast and Prostate Cancer Cohort Consortium (BPC3). Breast Cancer Res 2006;8:R54

69 Wooster R, Mangion J, Eeles R, Smith S, Dowsett M, Averill D, Barrett-Lee P, Easton DF, Ponder BA Stratton MR: A germline mutation in the androgen receptor gene in two brothers with breast cancer and Reifenstein syndrome. Nat Genet 1992;2: 132-134.

70 López-Capapé M, Alonso M, Gonçalves J, Barrio $\mathrm{R}$ : [Partial androgen insensitivity syndrome associated with familiar breast cancer]. Med Clin (Barc) 2005;124:598-599.

71 Lobaccaro JM, Lumbroso S, Belon C, GaltierDereure F, Bringer J, Lesimple T, Namer M, Cutuli BF, Pujol H, Sultan C: Androgen receptor gene mutation in male breast cancer. Hum Mol Genet 1993; 2:1799-1802.
72 Poujol N, Lobaccaro JM, Chiche L, Lumbroso S, Sultan C: Functional and structural analysis of R607Q and R608K androgen receptor substitutions associated with male breast cancer. Mol Cell Endocrinol 1997;130:43-51.

73 Hiort O, Naber SP, Lehners A, Muletta-Feurer S, Sinnecker GH, Zöllner A, Komminoth P: The role of androgen receptor gene mutations in male breast carcinoma. J Clin Endocrinol Metab 1996;81: 3404-3407.

74 Gottlieb B, Beitel LK, Wu JH, Trifiro M: The androgen receptor gene mutations database (ARDB): 2004 update. Hum Mutat 2004;23: 527-533.

75 Zhu X, Daffada AA, Chan CM, Dowsett M: Identification of an exon 3 deletion splice variant androgen receptor mRNA in human breast cancer. Int J Cancer 1997;72:574-580.

76 Shan L, Yang Q, Nakamura M, Nakamura Y, Mori I, Sakurai T, Kakudo K: Active allele loss of the androgen receptor gene contributes to loss of androgen receptor expression in female breast cancers. Biochem Biophys Res Commun 2000;275:488-492.

77 Secreto G, Toniolo P, Pisani P, Recchione C, Cavalleri A, Fariselli G, Totis A, Di Pietro S, Berrino F: Androgens and breast cancer in premenopausal women. Cancer Res 1989;49:471-476.
78 Kaaks R, Rinaldi S, Key TJ, Berrino F, Peeters PHM, Biessy C, Dossus L, Lukanova A, Bingham S, Khaw K, Allen NE, Bueno-de-Mesquita HB, van Gils CH, Grobbee D, Boeing H, Lahmann PH, Nagel G, Chang-Claude J, Clavel-Chapelon F, Fournier A, Thiébaut A, González CA, Quirós JR Tormo M, Ardanaz E, Amiano P, Krogh V, Palli D, Panico S, Tumino R, Vineis P, Trichopoulou A, Kalapothaki V, Trichopoulos D, Ferrari P, Norat T, Saracci R, Riboli E: Postmenopausal serum androgens, oestrogens and breast cancer risk: the European prospective investigation into cancer and nutrition. Endocr Relat Cancer 2005;12:1071-1082.

79 Rudlowski C: Male breast cancer. Breast Care 2008;3:183-189.

80 Goldenberg IS, Sedransk N, Volk H, Segaloff A, Kelley RM, Haines CR: Combined androgen and antimetabolite therapy of advanced female breast cancer. A report of the cooperative breast cancer group. Cancer 1975;36:308-310.

81 Karydas I, Fentiman IS, Tong D, Bulbrook RD, Hayward JL: Adjuvant androgen treatment of operable breast cancer - a 20 year analysis. Eur J Surg Oncol 1987;13:113-117.

82 Garreau JR, Muller P, Pommier R, Pommier S: Transgenic introduction of androgen receptor into estrogen-receptor-, progesterone-receptor-, and androgen-receptor-negative breast cancer cells renders them responsive to hormonal manipulation. Am J Surg 2006;191:576-580. 